\title{
THE STUDY OF TECHNOLOGICAL PARAMETERS OF PECTIN CONTAINING RAW MATERIAL PROCESSING IN THE VEGETABLE-MILK FORCEMEATS TECHNOLOGY
}

\author{
Grygoriy Deynychenko \\ Department of food and hotel industry \\ equipment named after M. I. Belyaev \\ Kharkov State University of Food Technology and Trade \\ 333 Klochkovsky str., Kharkov, Ukraine, 61051 \\ deynichenkogv@rambler.ru \\ Victoriya Gnitsevych \\ Department of Technology and \\ the organization of restaurant business \\ Kyiv National University of Trade and Economics \\ 19 Kyoto str., Kiev, Ukraine, 02156 \\ flamber65@yandex.ru \\ Tatiana Yudina \\ Department of Technology and \\ the organization of restaurant business \\ Kyiv National University of Trade and Economics \\ 19 Kyoto str., Kiev, Ukraine, 02156 \\ olegdmu@rambler.ru \\ Iryna Nazarenko \\ Department of technology in a restaurant \\ economy that hotel and restaurant business \\ Donetsk National University of Economics and Trade \\ named after Mykhailo Tugan-Baranovsky \\ 16 Ostrowski str., Krivoy Rog, Ukraine, 50005 \\ nazarenko5555@mail.ru \\ Olena Vasylieva \\ Department of Technology and \\ the organization of restaurant business \\ Kyiv National University of Trade and Economics \\ 19 Kyoto str., Kiev, Ukraine, 02156 \\ vasuleva2015@ukr.net
}

\footnotetext{
Abstract

The algorithm of the study that includes theoretical analysis and physical experiment was elaborated for the study of technological parameters of pectin containing raw material processing in the vegetable-milk forcemeats technology. The expedience of using carrot Shantenee, pumpkin Guiley and marrow Zolotinka as the sources of pectin substances in the technology of combined forcemeats on the milk base was grounded. Technological parameters of pectin containing raw material processing for realization of its target properties as an amendment and stabilizer of the structure in milk-vegetable forcemeats technology were theoretically grounded. The methods of determination of soluble pectin and protopectin content and also the methods of determination of $\mathrm{pH}$ medium were chosen.

The methods of experiment planning and mathematical processing of experimental data were carried out using computer programs MS Excel 972003 and MatCAD. The influence of pH medium, temperature and duration of thermal processing of carrot, pumpkin and marrow on the process of accumulation of soluble pectin in them was studied. The formation technology of puree of the vegetables that have the increased viscosity and are not stratified at the storage and further use. Accumulation of soluble pectin that expresses the properties of structure stabilizer and favors the increase of vegetable puree viscosity causes the expedience of its use in milk-vegetable forcemeats technology.
} 
The use of vegetable puree in milk-vegetable forcemeats technology allows widen the assortment and provide the mutual enrichment of the receipt components of combined forcemeat masses with milk proteins, $\beta$-carotene, food fibers, vitamins and other functional ingredients.

Keywords: puree of carrot, puree of pumpkin, puree of marrow, soluble pectin, amendment, milk-vegetable forcemeats.

\section{Introduction}

The worsening of socio-economic and environmental condition in Ukraine [1] favors the specific topicality of the necessity to improve the technology of traditional food products. The creation of products of the new generation with balanced composition, lowered energetic and raised biological value is no less important.

The combination of milk raw material with vegetable one $[2,3]$ is the prospective direction in creation of qualitatively new food products. The vegetable proteins in combination with animal ones create biologically active amino acid complexes [4]. It provides their physiological value and high assimilability. The use of pectin containing vegetable raw material gives the new properties of stabilizing character to the milk-vegetable system $[2,3]$.

The milk product, which contains no less than $50 \%$ of milk base and not more than $30 \%$ of vegetable or animal component is considered as combined one with vegetable or animal raw material [5].

The milk-protein concentrate (MPC) of buttermilk can be considered as the most prospective raw material in technology of food production, especially forcemeat masses [6]. Buttermilk MPC proteins contain besides casein the serum proteins, which number is $26 \%$ of protein mass. The distinctive feature of buttermilk protein composition is a presence of proteins of fatty beads proteins that are identical to the serum proteins by their electrophoretic properties [6].

As the studies proved it, buttermilk MPC proteins contain the level of irreplaceable amino acids that exceeds the FAO/WHO standard [7, 8], that testifies to the high biological value of product.

MPC in whole is a product with the natural set of vitally important mineral substances and water-soluble vitamins [6].

It is necessary to consider the use of vegetable raw material in the milk-vegetable forcemeats (MVF) technology from the position of realization of properties of pectin substances, namely the possibility to increase viscosity of dispersion medium and to act as the structure stabilizer.

Edible roots are characterized with the highest content of pectin substances. Thus, the table carrot is widely used in technology of dessert products [9], homogenized sanitary curd products [10], ice-cream [11]. Carrot contains 6,4...20,0 \% of pectin substances for dry substance with etherification degree $55 . .58 \%$ [12]. Among the gourd family that is marrows that are characterized with maximal content of pectin substances $(16,5 \ldots 17,6 \%$ ), a bit lower - custard marrow $(15,5 \ldots 16,9 \%)$, pumpkins $-13,5 \ldots 14,4 \%$, etherification degree of pectin substances of pumpkins is near $53 \ldots 58 \%$ [13, 14].

The generalized data of chemical composition of carrot, pumpkin and marrow sorts, districted in forest-stepped zone of Ukraine, prove that is expedient to use carrot Shantenee, pumpkin Guiley and marrows Zolotinka as the vegetable component in MVF technology [15].

The aim of the work is scientific grounding and experimental confirmation of technological parameters of pectin containing raw material processing for realization of its target properties as an amendment in the milk-vegetables forcemeats technology.

For attaining the set aim the following tasks were solved: to determine the influence of temperature and duration of the raw material thermal processing on the content of soluble pectin (SP); to ground the method of hydrolysis of protopectin into soluble pectin; to elaborate the method of production of carrot, pumpkin or marrow puree with given functional-technological properties.

\section{Materials and methods of research}

The subjects of research were: vegetable material (table carrot Shantenee, food pumpkin Guiley, marrows Zolotinka (Fig. 1), carrot, pumpkin, marrow puree. 


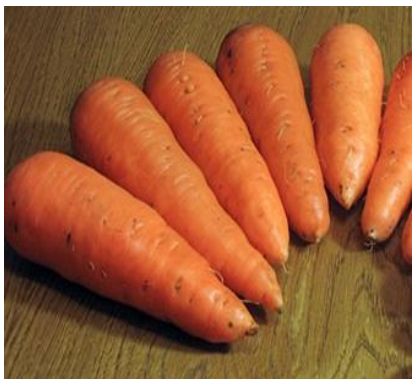

$a$

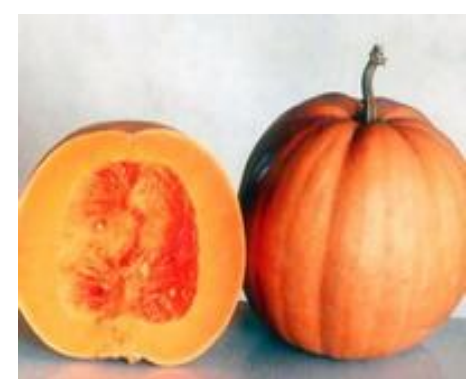

$b$

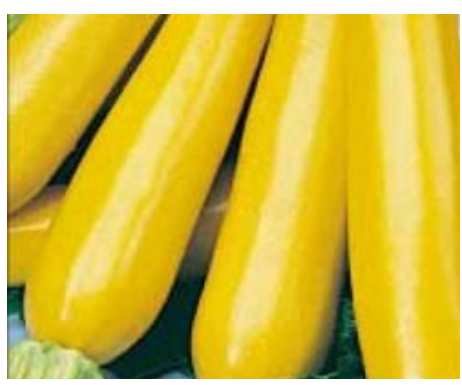

$c$

Fig. 1. Studies samples: $a$ - table carrot Shantenee; $b$ - food pumpkin Guiley; $c$ - marrows Zolotinka

The content of protopectin and soluble pectin was determined at the laboratory of Environmental monitoring and animal production quality department of the Institute of animal husbandry of Ukrainian academy of agrarian sciences (v. Kulinichy, Kharkov region, Ukraine), accredited by the certification system ISO/IES 17025:2006.

The methods of experiment planning and mathematical processing of experimental data were realized using MS Excel 972003 and MatCAD programs. All experiments were fivefold repeated for statistical reliability.

The study of pectin and protopectin content in vegetable puree was realized by calcium-pectate method [16].

For determination of mass share of pectin substances in the vegetable raw material, they were transformed into soluble state.

For this aim the sample of studied material with mass $25 \mathrm{~g}$ was taken, carefully pounded in mortar to the homogenous mass. It was qualitatively transferred in conic flask for $150 \mathrm{ml}$, mortar was washed with water, then $100 \mathrm{ml}$ of distilled water with temperature $40{ }^{\circ} \mathrm{C}$ were added in flask. The flask with material and water was kept on the water bath at temperature $40^{\circ} \mathrm{C}$ during $30 \mathrm{~min}$. After that the content of flask was filtered through the paper folded filter. The operation was repeated, flooding the solid residuum in flask with $75 \mathrm{ml}$, then once more time with $50 \ldots 60 \mathrm{ml}$ of water, filtering the liquid through the same filter each time. The received extracts were collected in the measuring flask for $250 \mathrm{ml}$ and added with distilled water up to the mark.

For determination of protopectin mass share in the vegetable raw material, the residuum of the crushed vegetable raw material on filter was flooded with $50 \mathrm{ml}$ of $0,3 \mathrm{H}$ solution of hydrochloric acid and transferred to the glass flask for $250 \mathrm{ml}$, the flask was closed with plug with reverse fridge and kept for $30 \mathrm{~min}$ on the boiling water bath. After that the extract was filtered through the folded filter into the measuring flask for $500 \mathrm{ml}$. The residuum on filter was washed 3, 4 times with $75 \mathrm{ml}$ of distilled water, the scourage was filtered through the paper filter in the same flask. The filter with residuum of the vegetable material was transferred in conic flask, flooded with $50-70 \mathrm{ml}$ of $1 \%$ solution of citric acid ammonium and placed on the boiling water bath for $30 \mathrm{~min}$. The received extract was filtered through the paper filter into the same measuring flask. Filter was washed with the hot distilled water with temperature $40{ }^{\circ} \mathrm{C}$, after that the content of flask was cooled and added up to the mark. The received extracts of hydrated pectin and protopectin were studied by calcium-pectate method, based on the precipitation of pectic acids as calcium salts. The analysis is the same at determination of pectins in both solutions. The difference is in the fact that protopectin solution is preliminary neutralized by $\mathrm{NaOH}$ up to the increase of alkalize necessary for its hydrolysis.

For hydrolysis of pectin substances the $50 \mathrm{ml}$ of studied solution were added with the equal volume of $0,4 \%(1 \mathrm{H})$ solution of $\mathrm{NaOH}$ and left for $8 \ldots 10$ hours at the room temperature $25^{\circ} \mathrm{C}$. After that the solution was acidified with the same volume of $1 \mathrm{H}$ acetic acid. The created pectic acids were precipitated by $50 \mathrm{ml}$ of $10 \%$ solution of $\mathrm{CaCO}_{3}$. The received residuum of calcium pectate was filtered through the paper filter, dried beforehand to the constant mass and weighted with weighing bottle. The residuum on filter was washed with $0,5 \%$ solution of $\mathrm{CaCl}_{2}$, then 5,6 times with the cold distilled water to eliminate the chlorine ions. For ash content decrease the residuum was additionally washed 3, 4 times 
with the hot distilled water with temperature $40^{\circ} \mathrm{C}$. Filter with residuum was transferred into weighing bottle and dried up to the constant mass at temperature $100 \ldots 105^{\circ} \mathrm{C}$. The residuum mass, received by the difference between the weighing bottle mass with residuum on the filter and weighing bottle mass with filter, was multiplied by 0,9235 for recalculation on pectic acid [16].

PH determination was realized using electrometric method. It is based on the measuring of EMF of the element that consists of 2 electrodes. The first electrode is the one of comparison with the known potential value. The second measuring $\mathrm{H}^{+}$selective electrode, which potential is caused by concentration of hydrogen ions in the studied object.

The measuring of $\mathrm{pH}$ was carried out using universal ionometer EV-74 (Gomel city, Belorussia, measuring instruments plant, 1981), set for pH-metry. The glass electrode was used as indicator, the chlorine-silver one - as the one of comparison.

The results of experimental studies were statistically processed by the least square method [17] for error estimation of the received data.

The calculations, estimation of reliability of experimental data and construction of graphs were carried out using the program MS Excel 972003.

\section{1. Experiments for the study of technological parameters of the raw material processing}

The grounding of technological parameters and regimes of vegetable puree production was realized as following:

- the influence of duration of carrot, pumpkin and marrows thermal processing (TP) on the content of soluble pectin was determined at the first stage;

- the influence of vegetables comminution temperature on the content of soluble pectin - at the second stage;

- the influence of temperature and duration of vegetable puree thermal processing on the content of soluble pectin - at the third stage;

- the influence of $\mathrm{pH}$ medium on the soluble pectin content in vegetable puree - at the fourth stage.

The vegetables were examined, washed, peeled, crushed into cubes with rib size $1=(0,8 \ldots 1) \times$ $\times 10^{-2} \mathrm{~m}$. Inactivation of oxidases in the vegetable raw material composition was carried out by the thermal processing of vegetables by steam at temperature $108 \ldots 112{ }^{\circ} \mathrm{C}$ at the beginning of technological process for prevention of significant destruction of vitamin $\mathrm{C}$ and other biologically active substances [18]. The results of TP influence on SP content in the raw material are presented on the Fig. 2 (on the example of carrot).

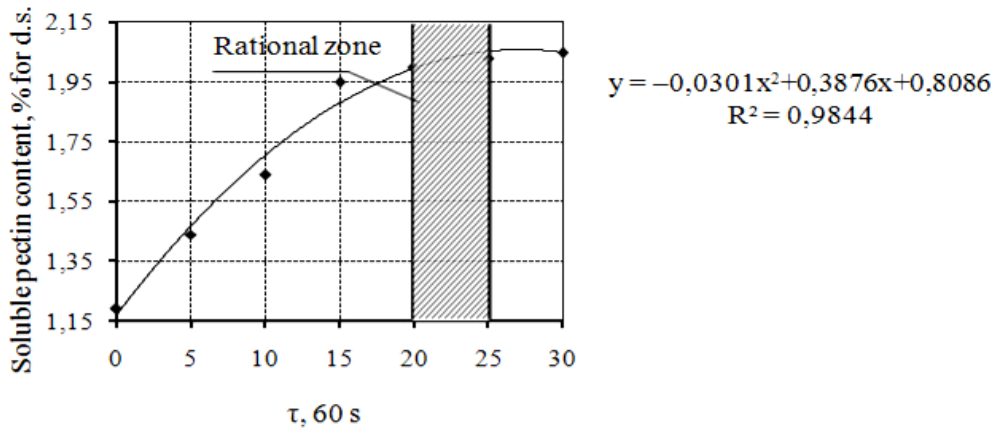

Fig. 2. The influence of carrot thermal processing duration on the soluble pectin content

To receive the puree-like products, vegetables after browning were crushed in the machine for thin comminution of boiled vegetables with seizes $(2 \ldots 8) \cdot 10^{-3} \mathrm{~m}$ with their further homogenization up to the seizes $(5 . .7) \cdot 10^{-4} \mathrm{~m}$ and less [18]. The results of the study of influence of the vegetables comminution temperature on the soluble pectin content are presented on the Fig. 3 (on the example of carrot).

It is possible to intensify the speed of pectin accumulation by the secondary thermal processing of crushed vegetables. It is known, that the temperature regime more than $80{ }^{\circ} \mathrm{C}$ leads to the destruction of biologically active substances of puree and negatively influences their food 
value. And at the temperature lower than $70{ }^{\circ} \mathrm{C}$ the proteins coagulation is not full. It also favors the destruction of polymers of cellular wall that limits the penetration of hydrolytic factor [19]. That is why at the next stage the influence of duration of vegetable puree processing on SP content was determined at temperature $70 \ldots 80{ }^{\circ} \mathrm{C}$. The results of research (on the example of carrot) are presented on the Fig. 4.

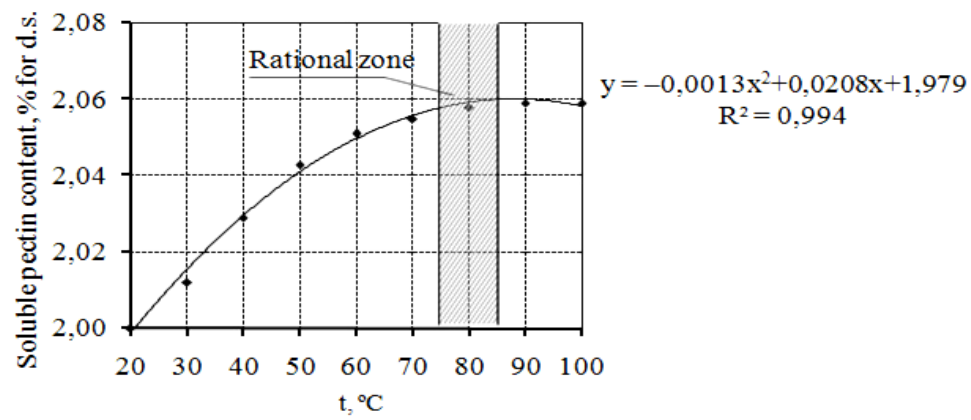

Fig. 3. The influence of carrot comminution temperature of on the soluble pectin content in it
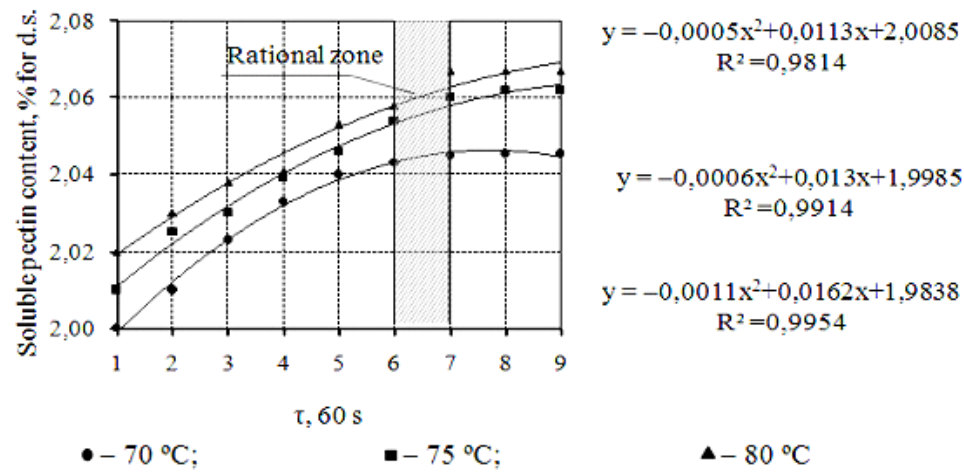

Fig. 4. The influence of temperature and duration of carrot puree thermal processing on the soluble pectin content

On the base of analysis of the methods of vegetable purees and pasts production [18] it was established, that hydrolysis of protopectin takes place more intensively in the acid medium. PH regulations were carried out by introduction of lemon acid that additionally allows decrease the losses of $\beta$-carotene, connected with its oxidation. The results of the study of $\mathrm{pH}$ medium influence on the soluble pectin content in vegetable puree are presented on the Fig. $\mathbf{5}$ (on the example of carrot puree).

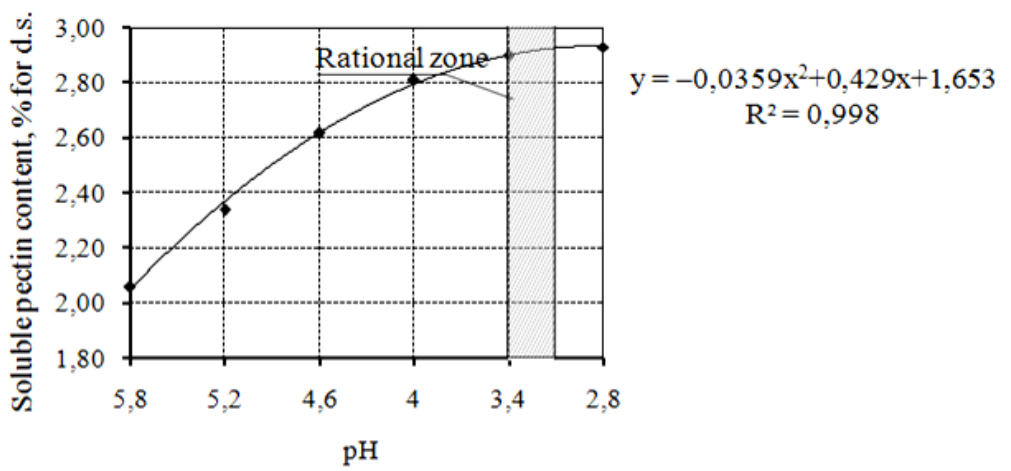

Fig. 5. The influence of $\mathrm{pH}$ medium on the soluble pectin content in carrot puree

The received results (Fig. 5) testify that $\mathrm{pH}$ change has significant influence on the SP content in carrot puree. 
The analogous experiments were carried out for the study of technological parameters of pumpkin and marrow processing.

\section{Results of research}

It was established (Fig. 2), that maximal quantity of SP is observed in $(20 \ldots 25) \cdot 60 \mathrm{~s}$ for the carrot and pumpkin and in (15...20).60 s for marrows. The results of the study of influence of thermal processing duration on pectin content in vegetables are presented in the Table 1.

Table 1

The influence of thermal processing on the soluble pectin content in vegetables

\begin{tabular}{ccc}
\hline Object of research & \multicolumn{2}{c}{$\begin{array}{c}\text { Soluble pectin content of, \% for d.s. } \\
\text { After thermal processing }\end{array}$} \\
\hline Carrot Shantenee & 1,17 & 2,03 \\
Food pumpkin Guiley & 5,83 & 9,83 \\
Marrows Zolotinka & 4,00 & 7,65
\end{tabular}

The results of the study of vegetables comminution temperature influence on the soluble pectin content in them (Fig. 3) testify that SP content has the maximal values at vegetables comminution temperature $75 \ldots 85^{\circ} \mathrm{C}$, at which the destruction of connections between pectin substances and other substances of cellular walls takes place, and at the lower temperature only maceration of tissues takes place. This tendency is traced for all objects of the study.

It was established (Fig. 4), that the secondary TP of carrot puree leads to the increase of SP content in it. The analogous tendency was traced also for the puree of pumpkin and marrows. Under aforesaid conditions the rational TP duration that provides the maximal growth of SP content in vegetable puree at preservation of their qualitative parameters is $(6 \ldots 7) \cdot 60 \mathrm{~s}$.

It is worth noting, that the more intense accumulation of water-soluble pectin is observed in marrows that can be explained by the low etherification degree of its pectin (near $40 \%$ ) and by the protopectin destruction especially as the result of ion-exchanging processes.

The rational $\mathrm{pH}$ value for protopectin transformation into soluble pectin and preservation of qualitative parameters of carrot puree is 3,0...3,4 (Fig. 5). The $\mathrm{pH}$ decrease leads to insignificant changes in the soluble pectin content and increase of acidity of all studied objects that worsens their organoleptic parameters and quality.

The production of vegetable puree is realized as following. The carrot Shantenee, pumpkin Guiley or marrow Zolotinka are examined, washed and peeled, crushed in cubes with rib size $l=(0,8 \ldots 1) \cdot 10^{-2} \mathrm{~m}$ and thermally processed. The parameters of pectin containing raw material processing are given in the Table 2.

Table 2

The parameters of pectin containing raw material processing

Values of thermal processing parameters

Thermal processing parameters carrot pumpkin

marrow

Thermal processing of vegetables

\begin{tabular}{|c|c|c|}
\hline Method and temperature & By steam, $\mathrm{t}=108 \ldots 112$ & \\
\hline Duration & $\tau=(20 \ldots 25) \cdot 60 \mathrm{~s}$ & $(15 \ldots 20) \cdot 60 \mathrm{~s}$ \\
\hline \multicolumn{3}{|c|}{ Comminution of vegetables } \\
\hline Temperature & $\mathrm{t}=75 \ldots 85^{\circ} \mathrm{C}$ & \\
\hline Sizes of puree particles & $\mathrm{d}=(5 \ldots 7) \cdot 10^{-4} \mathrm{~m}$ & \\
\hline \multicolumn{3}{|c|}{ Puree thermal processing } \\
\hline Temperature & $\mathrm{t}=70 \ldots 80^{\circ} \mathrm{C}$ & \\
\hline Duration & $\tau=(6 \ldots 7) \cdot 60 \mathrm{~s}$ & \\
\hline $\mathrm{pH}$ of medium & $3,0 \ldots 3,4$ & \\
\hline
\end{tabular}


Vegetable purees, received by the offered methods, have a consistence that is smeared and is not stratified at storage and further use. Accumulation of soluble pectin that expresses the properties of structure stabilizer and favors the viscosity of vegetable puree conditions the expedience of their use in MVF technology.

\section{Conclusions}

1. Technological parameters of the raw material processing for realization of their target properties as an amendment in milk-vegetable forcemeats technology were grounded: vegetables TP temperature $-110 \pm 2{ }^{\circ} \mathrm{C}$, vegetables TP duration - $(20 \ldots 25) \cdot 60 \mathrm{~s}$ for carrot and pumpkin and $(15 \ldots 20) \cdot 60 \mathrm{~s}-$ for marrows. grounded.

2. The expedience of the use of acid hydrolysis using lemon acid as $\mathrm{pH}$ regulator was

3. The method of carrot, pumpkin, marrow puree production was elaborated: the temperature of vegetables comminution $-80 \pm 5^{\circ} \mathrm{C}$, temperature of puree TP $-75 \pm 5^{\circ} \mathrm{C}$, TP duration $-(6 \ldots 7) \cdot 60 \mathrm{~s}$ and $\mathrm{pH}$ medium - 3,0...3,4.

Vegetable purees, received by the offered methods, have a consistence that is smeared and is not stratified at storage and further use. They may be used in culinary production technology to widen its assortment, enrichment with $\beta$-carotene, food fibers, mineral substances and other functional ingredients.

The technology of the milk-vegetable forcemeat production using vegetable puree, received by the offered methods, was elaborated. The further use of milk-vegetable forcemeats in dishes and culinary products technology allows widen the assortment of restaurant production, raise their food and biological value. That is why the prospects of further studies are the elaboration of the series of new technologies of manufacturing dishes and culinary products on the base of milk-vegetable forcemeats.

\section{References}

[1] Podlesnaia, V. G. (2015). Osobennosti sovremennogo sotsialno-ekonomicheskogo krizisa v Ukraine i osnovnye orientiry ego preodoleniia. Ekonomika Ukrainy, 6, 74-81.

[2] Rudakova, A. Yu., Zabodalova, L. A., Serova, O. P. (2014). Razrabotka i proizvodstvo syrnykh produktov s rastitelnymi komponentami. Nauchnyi zhurnal NEU ITMO. Seriia «Protsessy i apparaty pishchevykh proizvodstv», 4, 204-209.

[3] Shatniuk, L. N., Kodentseva, V. M., Vrzhesinskaia, O. A. (2010). Obogashcheniie molochnykh produktov: nauchnoe obosnovaniie, normativnaia baza, prakticheskiie resheniia. Molochnaia promyshlennost, 10, 34-39.

[4] Pasko, O. V. (2006). Nauchnye i prakticheskie aspekty tekhnologii proizvodstva molochno-rastitelnykh produktov: monografiya. Omsk: OmGAU, 336.

[5] Romanova, V. V. (2005). Proektirovaniie geleobraznykh produktov s ispolzovaniem molochnoi syvorotki i rastitelnogo syria. Kemerovo, 18.

[6] Yudina, T. I. (2000). Oderzhannia molochno-bilkovogo kopretsypitatu zi skolotyn i doslidzhennia yogo yakisnykh pokaznykiv. Visnyk DonDUET. Tekhnichni nauky, 6, 60-64.

[7] Geisow, M. (1977). Serum albumin structure and function. Nature, 270 (5637), 476-477. doi: $10.1038 / 270476 \mathrm{a} 0$

[8] Kühnau, J. (1949). Biochemie des Nahrungseiweißes. Angewandte Chemie, 61 (9), 357-365. doi: 10.1002/ange.19490610904

[9] Golubeva, L. V., Melnikova, E. I., Tereshkova, E. B. (2006). Ovoschnye napolniteli v kombinirovannykh molochno-rastitelnykh sistemakh. Estestvoznanie i gumanizm, 3 (2), 57. 
[10] Pavliuk, R. Yu. At al. (2010). Nanotekhnologii gomogenizovanykh ozdorovchykh syrkovykh produktiv, zbagachenykh nanostrukturovanymy BAD iz produktiv bdzhilnytstva. Molokopererobka, 3 (54), 16-22.

[11] Molokanova, L. V. (2012). Innovatsii u vyrobnytstvi morozyva - ovochevi napovniuvachi. Produkty \& ingredienty, 2 (88), 40-42.

[12] Goralchuk, A. B. (2006). Doslidzhennia kompleksoutvoriuiuchoi zdatnosti pektynovykh rechovyn morkvianogo piure. Visnyk Harkivskogo natsionalnogo tekhnichnogo universytetu silskogo gospodarstva imeni Petra Vasylenka, 45, 220-226.

[13] Odarchenko, D. M., Dubinina, A. A., Zinchenko, O. V. (2002). Doslidzhennia karotyniv u protsesi zberezhennia zamorozhenykh past na osnovi morkvy ta garbuza. Vestnik Khersonskogo gosudarstvennogo tekhnicheskogo universiteta, 3, 415-418.

[14] Telezhenko, L. N., Bezusov, A. T. (2004). Biologicheski aktivnye veshhestva fruktov i ovoshhei i ikh sokhraneniie pri pererabotke. Odessa: «Optimum», 268.

[15] Yudina, T. I., Nazarenko, I. A. (2012). Obgruntuvannia vyboru roslynnoi syrovyny dlia vyrobnytstva kombinovanykh farshiv. Obladnannia ta tekhnologii kharchovykh vyrobnytstv, 29 (2), 322-328.

[16] Averianova, E. V., Shkolnikova, M. N. (2015). Pektin: metody vydeleniia i svoistva: metodicheskie rekomendacii k vypolneniiu laboratornykh rabot. Bijsk: Izdatel'stvo Altajskogo gosudarstvennogo tehnicheskogo universiteta, 42.

[17] Piriaatin, V. D. (1982). Obrabotka rezultatov eksperimentalnykh issledovanii po metodu naimenshyk kvadratov. Kharkov: KGU, 213.

[18] Pogarskaia, V. V., Cherevko, A. I., Pavliuk, R. Yu. At al. (2007). Novye tekhnologii funktsionalnykh ozdorovitelnykh produktov. Kharkiv: Khar'kovskij gosudarstvennyj universitet pitanija i torgovli, 262.

[19] Krapyvnytska I. O. (2012). Sposib vyrobnytstva pektynovmisnogo ovochevogo piure: pat. 73050 Ukraina, 17, 5. 